\title{
EHMTI-0286. Hemicrania epileptica: case report
}

\author{
F Traverso $^{1^{*}}$, M Fasciglione $^{2}$, F Alberti $^{1}$ \\ From 4th European Headache and Migraine Trust International Congress: EHMTIC 2014 \\ Copenhagen, Denmark. 18-21 September 2014
}

Headache occurring during partial seizure, ipsilateral to the epileptic discharge, and remitting immediately soon after the seizures has terminated, is mentioned in IHS Classification 3rd edition (7.6.1). We here report the case of a misunderstood partial epilepsy, headache being considered the main problem. A fifty years old woman presented with a ten days history of stabbing left lateralized headache. The attacks were short-lasting ( $<3$ minutes), at least forty or more every day, neuralgiform without conjunctival injection or tearing, but always associated with elementary hallucination (a bright light) in the right hemifield. She had a a history of very severe head trauma at age twenty-one, with left hematoma evacuation, followed by hydrocephalus, installation of ventriculo-peritoneal shunt complicated by meningitis. She had the same headache attacks at age thirty for a period of three months. She took several analgesic preparation every day with benefit on headache but not on right sided hallucinations. EEG showed left spikes discharges on the left temporo-occipital regions occurring during the headache with hallucinations attacks and remitting immediately after the seizures has terminated. CT demonstrated left porencephalic cavity, ex vacuo dilatation of left lateral ventricle, left temporo-parietal fracture, ventricolo-peritoneal catheter in right lateral ventricle. The seizures remitted with antiepileptic therapy (levetiracetam $500 \mathrm{mg}$ twice daily). Our case report demostrates the importance of considering the differential diagnosis of epilepsy in stabbing headache even when analgesic sensitive.

No conflict of interest.

\section{Authors' details \\ ${ }^{1}$ Neurology, ASL 1 IMPERIESE, Sanremo, Italy. ${ }^{2}$ Radiolology, ASL 1 IMPERIESE, Sanremo, Italy.}

Published: 18 September 2014

${ }^{1}$ Neurology, ASL 1 IMPERIESE, Sanremo, Italy

Full list of author information is available at the end of the article
doi:10.1186/1129-2377-15-S1-C61

Cite this article as: Traverso et al: EHMTI-0286. Hemicrania epileptica:

case report. The Journal of Headache and Pain 2014 15(Suppl 1):C61.

\section{SpringerOpen ${ }^{\odot}$}

(C) 2014 Traverso et al; licensee Springer. This is an Open Access article distributed under the terms of the Creative Commons Attribution License (http://creativecommons.org/licenses/by/2.0), which permits unrestricted use, distribution, and reproduction in any medium, provided the original work is properly cited.
Submit your manuscript to a SpringerOpen ${ }^{\circ}$ journal and benefit from:

$\checkmark$ Convenient online submission

- Rigorous peer review

- Immediate publication on acceptance

- Open access: articles freely available online

- High visibility within the field

- Retaining the copyright to your article

Submit your next manuscript at $\boldsymbol{~ s p r i n g e r o p e n . c o m ~}$ 